FILOZOFIA

Roč. 77,2022 , č. 1

DOI: https://doi.org/10.31577/filozofia.2022.77.1.2

\title{
FICINO'S DOCTRINE OF LOVE AND BEAUTY AND ITS PLOTINIAN BACKGROUND
}

SONJA WEISS, University of Ljubljana, Faculty of Arts, Departement of Classics, Ljubljana, Slovenia

WEISS, S.: Ficino's Doctrine of Love and Beauty and its Plotinian Background

FILOZOFIA, 77, 2022, No 1, pp. $20-35$

This article analyses and compares the doctrines of love and beauty in the relevant works of Plotinus and Ficino, focusing on their allegorical use of the mythology of Aphrodite/Venus and Eros/Amor in their treatises On Love. As a translator and commentator of the collected works of his admired predecessors, Plato and Plotinus, Ficino did not hesitate to slightly bend, or even circumvent, some of their doctrines in his quest for the unification of the Platonic philosophy. Analysing the relevant passages from the Enneads, this article will demonstrate how Plotinus' emanation theory, as well as his doctrines of love and intelligible beauty, have influenced Ficino's interpretation of Plato's doctrine of love, as well as his own exegesis of God's love and creation.

Keywords: Ficino - Plotinus - Myth - Allegory - Love - Venus

\section{Introduction}

This article focuses on Ficino's creed of love which, typically, displays conjoined religious and philosophical traits. The historical background of his commentary to Plato's Symposium, bearing the title De amore liber, is a banquet, allegedly organised by Francesco Bandini at the instigation of Lorenzo de' Medici, at Careggi in 1468 , with the intention of restoring the ritual symposia that used to be held every year on the day of Plato's birth (November $7^{\text {th }}$ which was believed to be also the day of his death). This Ancient Platonic tradition had been disrupted since Porphyry's time, 1200 years earlier, Ficino writes in the prologue. ${ }^{1}$ The tractate, originally written in Latin, was later translated into Italian by Ficino himself. It shows the

\footnotetext{
${ }^{1}$ For the arguments concerning the origins of the work and the date of the alleged symposium, see Marcel in: Ficin (1956, 25 - 30). According to Ficino's letters, there were two events: the first one was organised during the day in Florence, where the debate covered the soul, and the other was held in the evening of the same day at Careggi, discussing the subject of love. On the doubts regarding the historical circumstances of the two events, see Laurens in: Ficin (2012, XIII - XVI).
} 
importance of the work and the author's desire to make it as accessible as possible. ${ }^{2}$ It had, indeed, a widespread influence on the surge of similar tractates, following Ficino's example by spreading the doctrine of love. ${ }^{3}$ Ficino's text follows that of Plato closely, in the form of seven discourses pronounced by Ficino's friends and colleagues. The work opens with a reverent mention of Plato, father of philosophers, but the content turns out to exceed the nature of commentary, rising to an original meditation on love inspired not only by Plato, but also by other philosophical, theological and mystical texts. It has been observed by modern commentators that Plato's Symposium is not a homogenous philosophical work, since many of its parts express the opinions of sophists and rhetors who do not share Plato's (or Socrates') philosophical beliefs. It would, therefore, be rash to attribute to Plato every statement given in these speeches. ${ }^{4}$ Ficino's commentary, on the contrary, unfolds with invariable philosophical earnestness ${ }^{5}$ aiming at uniformity of the Platonic doctrine. ${ }^{6}$

Plotinus, of course, is prominent among Ficino's sources, and De amore is no exception, although it was published more than twenty years earlier than Ficino's translation of the Enneads. Nevertheless, scholars have made a strong case, proving that Ficino had been working on Plotinus for some thirty years before publishing the Latin Enneads and commentaries to them and, at least from 1460, when he first got access to the Greek manuscript, which he had transcribed, making a habit of marking it with numerous annotations. ${ }^{7}$ It appears that Ficino paid particular attention to Plotinus' treatise On Eros (Enn. III 5(50)) of which two versions of Ficino's translation survive. Wolters has convincingly argued that Plotinus' doctrines, and not only the one in the $50^{\text {th }}$ tractate, but also other tractates, shaped Ficino's doctrine of love which, according to his arguments, should be understood in light of his

\footnotetext{
${ }^{2}$ While this paper was in the making, Ficino's Italian version of De amore first saw light in Slovene translation of Mojca Mihelič, accompanied by a comprehensive study of Igor Škamperle.

${ }^{3}$ For these works and their philosophical and literary value, see Panofsky (1972, $144-146$ ), and Škamperle in: Ficino (2021, 180 - 182), whose review of most notable authors also includes a prolific Croatian humanist Frane Petrić and his Amorous Philosophy (Amorosa filosofia) inspired by Ficino's dialogue.

${ }^{4}$ Laurens in: Ficin (2012, XXVII).

${ }^{5}$ As observed by Blum in: Ficino (2014, XVII).

${ }^{6}$ A recent study on Ficino's hermeneutics, however, observes that Ficino's unitary approach to Platonic texts does not preclude the probability that his De amore was inspired by actual conversations that took place at Florentine Platonic symposia. The same study also points out that the dialogic roles were carefully distributed by the author in a manner that befitted both Ficino's contemporaries and Plato's interlocutors (Robichaud $(2015,115)$ ).

${ }^{7}$ Wolters $(1986,192)$, who also refers to Henry (1948). For evidence of Ficino's early familiarity with Plotinus, see also Corrias (2020, $16-21)$.
} 
interpretation of Plotinus, even more than through his understanding of the original text of Plato. ${ }^{8}$

With these arguments in mind, I shall proceed to the analysis of Ficino's theory of love and beauty: first, I shall compare the mythological symbolism of Venus and Amor in the work of both philosophers, and then I shall observe more closely some passages from the Enneads, the examination of which in some of the cases points to Ficino's deviation from Plotinus, while in others, it displays his profound knowledge and subtle understanding of Plotinus' philosophy that allowed him to attune the latter's doctrines to his own.

\section{The Two Venuses and the Inner Tension of the Soul}

The second book of De amore opens with the formulation of the Neoplatonic principle of emanation, according to which everything that steps forth, so to speak, out of the Good, turns back to its source, thus receiving being and formation. ${ }^{9}$ Ficino, relying heavily on the Proclean Cylic theory of Causation, ${ }^{10}$ marks this process with the three steps of processio, conversio and perfectio, which represent the beginning (Deus creat), the middle (rapit) and the completion (perficit), with reference to the mystical Pythagorean Triad and Orphic conception of the all-embracing Zeus, who is the beginning, the middle and the end (De amore II.1). The second, revertive phase (conversio / Deus rapit) has already been emphasised in the first speech where it is said that the angelic Mind is born, as its dark essence turns toward its source, God, like an eye which is directed toward the light of the sun. This first conversio is actually called "the birth of Love (amoris ortus)" (I.3). ${ }^{11}$ On the other hand, the turn back towards the origins (epistrophé) was already an important part of Plotinus' love doctrine: it occurs at the level of the third Hypostasis, the Soul, represented by the heavenly Aphrodite, directing her love (éros) to her father, the source of her

\footnotetext{
${ }^{8}$ Wolters $(1986,189)$. Between the two colossal enterprises of translating and commenting on the entire opera of Plato and Plotinus, Ficino apparently found ample time to write his own works and to study and translate other Ancient thinkers who shaped his spiritual world. Among these were many post-Plotinian Neoplatonists (Iamblichus, Proclus, Ps. Dionysius among others), which is why some scholars argue that Ficino's Platonism is closer to post-Plotinian Platonic tradition than Plotinus' thought (or Plato's, for that matter); see Celenza (2002, $77-82)$.

${ }^{9}$ Cf. Plotinus, Enn. V 4(7).2.4 - 5. in V 1(10).7.5 - 6. V 2(11).1.8 - 12. For a detailed commentary on some of these passages, see Bussanich (1988, 7 - 54).

${ }^{10}$ See Proclus El. Th. 35, although Ficino seems to have followed Ps. Dionysius in his emphasis on the revertive phase of emanation (Gersh $(2019,30))$. For a historical overview of this doctrine, see Dodds in: Proclus (1963, 220 - 21).

${ }^{11}$ The concept of conversion acquires a moral, as well as mystical significance in light of Ficino's conviction that the goal of Platonism is assimilation to God and that it is love that makes us godlike; see Robichaud (2015, 13 - 17, 96, 120, and particularly 122 - 129) for Ficino's adjustment of Plotinus' ethical doctrine.
} 
existence (Enn. III 5(50).2). Her act is presented as a loving contemplation with Eros as her "eye" and the crucial link that keeps the Soul in contact with the intelligible realm. The second Hypostasis - Intellect/Nous - does not need such an eye, since it contemplates the One/Good within itself. However, even within the Intellect, a similar dynamic can be observed. P. Hadot explains the three "states" of Plotinus' Intellect (being, life and intellection) as the undeployed state (being, esse), the stepping out of itself (life, vivere), and the return to itself (intellection, intelligere). ${ }^{12}$ With this trinity of being-life-intelligence, Plotinus enlivened the stately dignity of the self-contemplating Intellect and, moreover, he reaffirmed the basic principle of the Good, giving itself, and thus giving (metaphysical) birth to what comes after it. If intelligere is the key moment of the reversion towards the principle, vivere is the critical moment of the progression, i.e., of the continuance of the emanation, leading to the birth of the Soul and finally to the generation of the cosmos. This double act is comparable to the bending of a bow, for it produces a tension which preserves the status quo, that is the stillness of the intelligible world. While the life is drawn forth, outside, and to generation, the intelligence turns back to contemplation. Strictly speaking, the progression is not opposed by any revertive motion, but by metaphysical rest: for the new-born reality (the Soul) does not aim to return to where it came from (which would disprove the generosity of the Good), but to keep a certain balance by preserving the link to the principle without putting a stop to its progression.

In De amore II.7, the intelligible triad of being, life and intellection is said to reflect in the similar triad at the level of the World Soul: intellection, movement and generation, symbolised by the same triad of gods in both cases: Saturn, Jove and Venus.

$$
\begin{aligned}
\text { MIND } & =\text { esse }(\text { Saturn }) & \text { SOUL } & =\text { intelligere }(\text { Saturn }) \\
& =\text { vivere }(\text { Jove }) & & =\text { movere }(\text { Jove }) \\
& =\text { intelligere }(\text { Venus }) & & =\text { generare }(\text { Venus })
\end{aligned}
$$

From this scheme, it becomes evident that the aforementioned tension (between intelligere and generare, i.e., between contemplation of the higher reality and generation of lower things) is limited to the double figure of Venus. She is, so to speak, a personification of apparently opposing tendencies of turning to the source and proceeding to generation, while Saturn and Jove represent corresponding pairs

\footnotetext{
${ }^{12}$ See Hadot (1957), for the history of this doctrine developed inside Plotinus' polemics with the stoics. Plotinus' trinity within the Intellect was inspired by a passage of Plato's Sophist, according to which Being cannot lack intellection, life nor even motion and soul.
} 
of esse/intelligere and vivere/movere. She is the focus of duality, which has a rich philosophical, as well as cultural, background.

Ficino's explanation of the two Venuses forms part of his commentary on Pausanias' speech in Plato's Symposium, which introduces two Aphrodites accompanied by corresponding Eroses: the elder one is the heavenly Aphrodite, daughter of Ouranos, while the younger one is the popular Aphrodite, daughter of Zeus and Dione (Symp. 180d-e). Since the speech is essentially about Eros, the details on each Aphrodite come forth gradually and succinctly. One of the reasons may be that ancient readers were well acquainted with the double role of the goddess of love. A similar distinction can be found in the Symposium of Xenophon (8.9-10), who mentions both cults presenting the heavenly Aphrodite as patroness of pure love of souls and beautiful deeds, and the other one as champion of bodily love. Xenophon's differentiation does not diverge from Plato's by much, except that the latter views the Eros of the heavenly Aphrodite as strictly homoerotic, while the lower Eros is more corporeal and directed to women as well. This antithetic presentation of Eros does not exactly match the features of the cults of the two Aphrodites, which show no such clear distinctions. ${ }^{13}$ Some studies, therefore, argue against a consistent, unambiguous binary perception of the concept of Aphrodite/Venus and Eros/Amor, since numerous texts display different dichotomies (between love, bodily and spiritual, adulterous and conjugal or, in our case, between intellection and generation): ${ }^{14}$ in light of this argument, even the minor difference between Plato's and Xenophon's dichotomy is revealing. Regarding the Renaissance, it seems even harder to speak of an unequivocal symbolism of the heavenly and the popular (or terrestrial) Venus, particularly in art, ${ }^{15}$ where Ficino's spiritual influence is sometimes said to surpass even his impact on philosophy. ${ }^{16}$ As we shall see, Ficino influenced by Plotinus, availed himself of the duality of Venus and corresponding Amors to make further distinctions. ${ }^{17}$

\footnotetext{
${ }^{13}$ Pirenne-Delforge (1988, 147 - 151).

${ }^{14}$ For the Medieval perception of Venuses and Cupids, see Tinkle (1996, 9 - 41).

${ }^{15}$ In his studies on the Neoplatonic background of Renaissance masterpieces (Botticelli's Birth of Venus and La Primavera, or Titian's Allegory of Sacred and Profane Love, among others) Panofsky gives an interpretation of the two figures, nude and clothed, based on Ficino's doctrine of the two Venuses, at the same time pointing out the double symbolism of nudity which, in moralistic doctrines, is a sign of bawdiness and debauchery, while its theological meaning often points to the freedom from secular burden and, consequently, represents a higher principle (Panofsky (1972, 151 60, and Id. 1970, 188 - 200)). See also Uršič (2002, 186 - 189), who defends a singular Venus uniting human and divine, sensual and spiritual, against Gombrich's interpretation (1945, reprd. 1972) of Botticelli's Venus in La Primavera as supra-sensual, divine idea of humanitas.

16 Škamperle $(2002,69)$.

${ }^{17}$ See, particularly De amore VI.5. and VI.8 and his Commentary to Plotinus' Enn. III 5(50).
} 
As goddess of love and beauty, Aphrodite is always accompanied by Eros. In one of his earlier treatises, Plotinus used this companionship to reinterpret the myth of Eros and Psyche, by identifying Aphrodite with Psyche, and conclude that "every soul is Aphrodite". (Enn. VI 9(9).9.31) The complexity of Plotinus' interpretation of this mythological motif is evinced in the treatise On Eros (Enn. III 5(50)), where he uses it as part of his elaborate doctrine of the soul, to illustrate the tension between the third Hypostasis' (i.e., the Soul's) turning back to its principle and progression to the sensible cosmos (Ch. 3). In his study of the treatise, P. Hadot states the problem of Plotinus' allegoresis of the two Aphrodites in the following way: after presenting and rejecting the first possible interpretation, according to which the heavenly Aphrodite symbolises the higher part of the World Soul, which does not turn to this world but dwells separate from it, while the second Aphrodite represents its lower part, which revives and governs the cosmic body, Hadot endorses the second explanation which, outside of the wider context of Plotinus' doctrine of the soul, seems also more acceptable. According to this explanation, the heavenly Aphrodite represents the Soul-Hypostasis, intent on contemplating the intelligible world, while the other Aphrodite represents the World Soul, engaged in the governing of this world. Comparing Ficino's interpretation of this motif in De amore with that of Plotinus, Hadot concludes that the accepted explanation of Plotinus' allegoresis is also more congruous with Ficino's interpretation of the two Venuses. ${ }^{18}$ Gersh's study of Ficino's commentary to Plotinus' fifth Ennead provides additional insight into the matter. His conclusions do not disprove Hadot's results, but his analysis of other relevant Ficino's texts neglected by Hadot (particularly his commentary to Enn. III 5(50)) reveals that Ficino's intricate structure of intelligible and psychic realms admits the second (rejected) interpretation of Hadot. ${ }^{19}$

In comparing Ficino's and Plotinus' theory of the two Venuses/Aphrodites, we must observe the following divergence, pointed out by the two studies: that, despite the overtly Plotinian character of Ficino's precession and reversion, Plotinus' three Hypostases were subjected to slight modification. As is evident from Ficino's commentary to Enn. III 5 (Chapter 2), the third Hypostasis - the Soul - had been replaced by the Intellectual Soul (see the scheme below), which is the Soul descending directly from the Angelic Mind (the intellectus simpliciter) and existing at two levels: as intellectus quidam (particular intellect), at the higher one, and as anima simpliciter (absolute Soul), at the lower one. What Ficino's Intellectual Soul has in common with Plotinus' third Hypostasis is perfect independence from the sensible world and the fact that it is completely absorbed in the contemplation of the

${ }^{18}$ Hadot in: Plotin (1990, $46-61$ ).

${ }^{19}$ Gersh in: Ficino (2017, cxxxiv - cxxxviii). 
intelligible realm from whence it came. Ficino's commentary results in the following scheme:

1. Intellect simpliciter

2. Intellectual Soul specified as the intellectual Soul that is in the World $=$ the first Venus

a. Intellect of a certain kind

b. Soul simpliciter

3. Life born from the Intellectual Soul $=$ conjoined World Soul $=$ the second Venus

a. Soul of a certain kind

b. Nature simpliciter ${ }^{20}$

This interpretation, presenting the first as well as the second Venus as two levels of the World Soul (her higher part linked to the Intellect, and the lower one to the body) seems, at first sight, to depart from the above given scheme from $D e$ amore II.7, as well as from a corresponding passage in VI.7, where the first Venus essentially represents mens angeli (Angelic Mind), and the second one mundi anima (World Soul). Trying to elaborate, Ficino adds that the First Venus is the intelligence inside the Angelic Mind, and this, as we have seen is the revertive phase of the Intellect corresponding to the Intellectual Soul of the scheme above: a Soul performing the act of intellection while being simply (simpliciter) a Soul, which corresponds to Plotinus' Soul-Hypostasis. This intricate interpretation can only be justified by the double nature of Venus, which first appears at the level of Intellect and then, by the trinitary analogy, resurfaces at the level of the World Soul.

Chapter VI.7 of Ficino's De amore reflects the attempt to unify the Platonic doctrine of love: even though the passage focuses on Diotima's myth of the birth of Eros, Ficino includes in it (as did Plotinus) Pausanias' distinction between the two Venuses (or the double Venus, gemina Venus). According to the scheme of II.7, the heavenly Venus, in this passage, still represents the intelligentia of the Angelic Mind. But, as the discourse in VI.7 continues, Ficino refines the meaning of the heavenly Venus: the intelligence of the Angelic Mind displays two distinct powers, potentia and vis intelligendi. Both Latin words mean "power", but the first one also means potency in the Aristotelic sense of unrealised possibility. ${ }^{21}$ This is exactly the

20 The scheme follows Ficino's text, but the English expressions are taken from Gersh in: Ficino (2017 and 2018).

${ }^{21}$ These two meanings are united in the Greek word dýnamis. It seems that Ficino tries to distinguish between the passive dýnamis of Venus (potentia intelligendi) and the active one, looking upwards (oculi vis, vis intelligendi). 
meaning of the potentia intelligendi, which, according to Ficino, is by its nature formless and dark, and thus represented by Eros' mother, Penia (meaning "poverty"). Ficino is, therefore, explicitly introducing the element of privation at the level of the Angelic Mind. This does not mean that he disregards the essential characteristic, the fullness of the Neoplatonic Intellect, for the unrealised potentiality of Penia is promptly met by the riches of the Angelic Mind, represented by Poros. Nevertheless, Penia stands for the darkness and lack of form inside this potentia intelligendi, which is actualised only with the arrival of the ray of light (radius), represented by Poros. Does that mean that Ficino has departed from Plotinus? Not necessarily: he compares this dark and formless power to the "the eye's power before the arrival of the sun"22 (vis oculi ante solis adventum), evoking Plotinus' metaphor of the "sight not yet seeing", which refers to the state of undefined desire of the Intellect trying to grasp the simplicity of its principle (Enn. V 3(49).11.4-5). There is another passage from Plotinus narrating the "birth" of the Intellect which, before actually becoming Intellect, "steps out" of the First Principle (= the One) as something other (állo): "This, when it has come into being, turns back upon the One and is filled, and becomes Intellect by looking towards it." (V 2(11).1.7-9). ${ }^{23}$ This other shows the qualities, or rather the un-quality and lack of form of the indefinite Dyad and intelligible matter ${ }^{24}$ which could be related to Plotinus' interpretation of Penia in III 5(50). Plotinus, however, does not speak of poverty in the intelligible world (the closest he comes to it is with the word "desire" in V 3(49)11.6), or "need" in VI 7(38).33.11) and he is always careful to stress the fullness of the Intellect (III 8(30).11.39). Also, in the tractate On Love, he directly connects Penia to the primary indetermination of Soul, not Intellect, before its turning back to the source (III.5(50).7). As matter, though an incorporeal entity, Penia is not included in Plotinus' hypostatic reality. She is mother of Eros and has nothing to do with the heavenly Aphrodite. It appears, then, that Ficino, while integrating Plotinus' process of emanation into his own metaphysics, took his interpretation of Penia and Poros to a higher level and did not hesitate to place Penia in the intelligible realm. This is evident also from other passages from Ficino's tractate referring to the darkness of the first substance (or essence) of the Angelic Mind (see De amore I.3 and V.11).

\footnotetext{
${ }^{22}$ English expressions and passages of Ficino's De amore are taken from Jayne's translation in: Ficino (1985).

${ }^{23}$ All passages from the Enneads are taken from Armstrong's translation in: Plotinus (1978 - 1988).

${ }^{24}$ See also Enn. V 4(7).2.7ss. and Rist $(1962,101-102)$.
} 


\section{Divine Love and Transcendent Beauty}

This makes us wonder what the balance of power is between Amor and Venus, which leads us to the question of priority in Ficino's metaphysical hierarchy. In $D e$ amore, amor seems to be at the top of this hierarchy. In the fifth speech given by Marsuppini, divine Love is, in a sense, older than the Angelic Mind, which God, the Father of everything, created "because of a certain love for the propagation of his own seed". (V.10) The divinus amor rises above all: not unlike Plotinus' Good, it proceeds to creation non coactus, sed sponte (V.11), and is older than Necessity, in which the Mind creates ideas. Ficino's generative first Love agrees with Plato's definition of Eros as love of "engendering and begetting upon the beautiful" (Sym. 206e), while Plotinus has replaced the first generation with procession (próodos), although he cannot always avoid expressions like "generation" and "creation", either. ${ }^{25}$ Nonetheless, he is very careful in his formulation of the generative impulse of the One/Good. To Plotinus, the timeless generation is the result of an inner necessity of the Good, coinciding with its will. We could call it "natural", since it is in the nature of Good to give itself forth. ${ }^{26}$ III 5(50), however, does not mention its love, for éros bears the Platonic connotation of poverty, and is therefore banned even from the level of the Intellect: as we saw, the first, heavenly Eros is born with the Soul-Aphrodite. Though it is the primal anagogical force, love is below Good and the Intellect.

There is love in Plotinus' Intellect, but of a different kind: in VI 7(38).35.1925 , it is an intoxication which, although referring to the description of the drunken Poros in Symp. 203b, ${ }^{27}$ reflects rather the ecstatic rapture and divine madness described in Plato's Phaedrus (251a-b). Thus, the Phaedrus vocabulary is used by Plotinus to describe the mystical union of the Intellect with its principle. ${ }^{28}$ The focus in the passage of VI 7(38) is evidently not on the generative or even less on the deficient trait of love. ${ }^{29}$

The two concepts of Platonic love (fullness and deficiency) in Plotinus are also addressed by Ficino in his commentary to Phaedrus. Here also, Ficino puts love at the top of the metaphysical hierarchy, so that the supreme God appears inseparable from his own desire to create.

\footnotetext{
${ }^{25}$ For example, próte hoîon génesis in Enn. V 2(11).1.7.

${ }^{26}$ See, Enn. V 4(7).1.27 - 39.

${ }^{27}$ See Lacrosse $(1994,97)$.

${ }^{28}$ Lacrosse $(1994,28-29)$

${ }^{29}$ In fact, in the treatise On Eros, Plotinus emphasizes this point by distinguishing between Poros' drunkenness and the fullness of the Intellect (III 5(50).9).
} 
Love is also god, that is, the god in whose presence love flourishes. Or rather, he is the highest god himself, for just as he can be called beauty in Plotinus, being the fountain of beauty, he can also be called love as the author of the love pursuing beauty. For when Plotinus puts the will first, he is about to deny not love itself, but assuredly the love that is poor (In Phdr., Summa 12).

The reference to Plotinus is of double interest. Firstly, it addresses the concept of love at the level of the One. Ficino's rather abrupt transition to the will, which "Plotinus puts first", is evidently referring to the treatise, On Free Will and the Will of the One (Enn. VI 8(39)). This is one of the most controversial of Plotinus' tractates for, at one point, speaking of the One, Plotinus relinquishes his habitual elliptical and apophatic discourse, and indulges in an "incorrect thinking" (Chs. 13-18), which is part of a methodology used deliberately to establish the perfect freedom of the First principle. It is in this context that Plotinus speaks of the love of One for itself:

And he, that same self, is lovable and love and love of himself, in that he is beautiful only from himself and in himself. For surely his keeping company with himself could not be in any other way than if what keeps company and what it keeps company with were the one and the same. But if what keeps company is one with what it keeps company with and what is, in a way, desiring is one with the object of desire, and the object of desire is on the side of existence and a kind of substrate, again it has become apparent to us that the desire and the substance are the same (VI 8(39).15.1-8).

These words could easily be applied to the Intellect or intelligible Beauty, where the subject of yearning and thinking coincides with the object. But the context leaves no doubt that Plotinus is speaking about the One/the Good. The love of the One for itself is a daring concept since it exposes the highest Principle to the element of privation. Ficino, distinguishing between the "sated" love and the indigent éros, is clearly aware of this, when he points out that Plotinus denies the love that is poor, and therefore substitutes it with will. ${ }^{30}$ But it appears that neither expression fits with what Plotinus had in mind:

\footnotetext{
${ }^{30}$ As Kristeller (2005, 282ss.), observed, love and will in Ficino are frequently intertwined through the concept of desire, particularly if we consider Ficino's definition of love as desiderium pulchritudinis.
} 
But he, since he has the highest place, or rather does not have it, but is himself the highest, has all things as slaves; he does not happen to them, but they to him, or rather they happen around him; he does not look to them, but they to him; but he is, if we may say so, borne to his own interior, as it were well pleased with himself, the pure radiance, being himself this with which he is well pleased (VI 8(39).16.9-12).

The expression used here (agapésas) is evidently metaphorical (hoîon hautòn agapésas). It does not express love for anything but itself and this love is clearly turned inwards. Rist has pointed out the development, in this treatise, of the doctrine of divine Eros, arguing that the love of the One for itself is to be understood as love for everything that is immanent in the $\operatorname{Good}^{31}$ and that, in its natural yearning for It, reaches mystical union with It. ${ }^{32}$ However, even if we do conceive the highest Love as turned to that which is in a sense within, it remains ostensibly non-creative and, most importantly, introvertive. The use of the word agapésas does stir interest, but it is impossible to prove that its meaning is much different from the éros used at the beginning of the Ch. $15 .{ }^{33}$ Many scholars do not support the traditional distinction between the Pagan Platonic éros as desire, born from privation, and the Christian charity (agápe). ${ }^{34}$ The only subtlety of meaning in the agapésas is the idea of pleasure, rather than love, charity or desire, which brings the word agapân closer to the verb hédesthai, used to express Intellect's happiness (see for example VI 7(38).31.5ss.).

Although I remain convinced that the personalised terminology of the $39^{\text {th }}$ tractate is to be taken as part of Plotinus' method of persuasion (VI 8(39).13.1-5), and therefore metaphorically ${ }^{35}$ (Plotinus himself is very emphatic about it), I agree with Lacrosse that, to dismiss it as such, without placing it in the context of Plotinus' discourse on the One, would be superficial. ${ }^{36}$ After all, Plotinus took pains to formulate the auto-erotic principle of emanation, and this formulation, together with the paradox of the One "being everywhere and nowhere" reflects, in many ways, the Platonic concept of Eros, as Lacrosse points out. ${ }^{37}$ But no matter how we understand the pleasure of the One in Itself, Plotinus' divine éros is not given the

\footnotetext{
${ }^{31}$ In the sense which is elaborated in the $22^{\text {nd }}$ tractate (Enn. VI 4(22).2 - 3).

${ }^{32}$ See Rist $(1964,78$ - 82).

${ }^{33}$ See Corrigan and Turner in: Plotinus $(2017,328)$, who point out the blending of these two expressions (erân, agapân).

${ }^{34}$ See Nygren $(1953,205$ - 207). For the critic of his thesis, see Armstrong (1961), and for the overview of the debate, Lacrosse $(1994,106-107)$. For later merging of these two concepts, see Rist $(1964,78-87)$.

${ }^{35}$ For the detailed argumentation, see the note in Leroux in: Plotin (1990, 355 - 358)

${ }^{36}$ Lacrosse $(1994,110)$.

${ }^{37}$ Lacrosse $(1994,118)$.
} 
prominent role of Ficino's procreative amor divinus as the driving force of the emanation. Plotinus' procession and reversion are reformulated by Ficino as the supreme Love, followed immediately by the reversive love. One should observe that these two forces do not correspond to the amores that attend the two Venuses, and of which it is the first one that turns back (contemplative love), and the second one that goes forth (generative love). These two amores are, in fact, just a reflection of a force that surpasses them both.

The claim that Plotinus calls the highest god beauty ${ }^{38}$ is another challenging interpretation of Ficino that requires further clarification of Plotinus' view on the relation between the Good and the Beauty. In his early treatises, Plotinus did not distinguish sharply between them: "In a loose and general way of speaking the Good is the primary beauty" (see I 6(1).6-7 and 9.39s). In his later works, however, the difference is more pronounced, particularly in the treatise On Intelligible Beauty, where the highest beauty is firmly anchored in the Intelligible world, ${ }^{39}$ while the One transcends everything, beauty included. Ficino's reference to Plotinus can be explained by a passage in the $38^{\text {th }}$ tractate where, speaking of the infinite first Principle, Plotinus calls it "beauty above beauty", and "generator" and "principle of beauty":

[...] so his beauty is of another kind and beauty above beauty. For if it is nothing, what beauty can it be? But if it is lovable, it would be the generator of beauty. Therefore, the productive power of all is the flower of beauty, a beauty which makes beauty. For it generates beauty and makes it more beautiful by the excess of beauty which comes from it, so that it is the principle of beauty and the term of beauty. But since it is the principle of beauty it makes that beautiful of which it is the principle, and makes it beautiful not in shape; but it makes the very beauty which comes to be from it to be shapeless, but in shape in another way; for what is called this very thing [shape,] is shape in another, but by itself shapeless. Therefore, that which participates in beauty is shaped, not the beauty (VI 7(38).32.29-39).

The next chapter, however, produces a vague reference to the transcendent object of soul's love and intellect's thought:

\footnotetext{
${ }^{38}$ See the quoted passage from Ficino's Commentary to Phaedrus above (Summa 12).

${ }^{39}$ See V 8(31).8.5ss., and even more so in V 5(32).12.
} 
$[\ldots]$ if it (sc. the intellect) thinks an individual, it has one intelligible shape; if it thinks all together it has a kind of variegated shape, still in need [and trying to discover] how it should contemplate that which is above that which is all-beautiful and variegated and not variegated (VI 7(38).33.8-12).

The English translation is that of Armstrong, but the Greek original is ambiguous about whether the attributes "all-beautiful" and "variegated and not variegated" are describing the transcendent or the transcended. Modern translations do not agree on this point: the translation quoted above is evidently among those which connect all three attributes to the transcended, i.e. the intelligible beauty, which makes the transcendent the first Good. ${ }^{40}$ A different reading of the text ("it is still in need, namely, of considering the Being beyond, the entirely beautiful, variegated and not variegated" in Plotinus, 2018 (ed. Gerson)) suggests that all three attributes should be applied to the transcendent and that the pánkalon, which is at the same time variegated and not variegated, is what the intellect is about to see. If this is the case, can we still speak of the transcendent as the first Principle, the Good? According to Bréhier, who also applies all three attributes to the transcendent, no: this beauty, variegated and not variegated, is still "au-dessous du Bien", ${ }^{41}$ and the translation "the Being beyond" in Gerson's edition concurs with that. There is also Hadot's explanation, antithetical to Bréhier's: for him, the pánkalon, whose variety is without variety, represents the Intellect (l'Esprit) who must look beyond it to this other reality. Hadot does not comment on this realité, but it must refer to the Good. In his commentary, though, Hadot introduces two beauties: "la Beauté une et multiple des Formes", which is the beauty of the Intellect, and "la vraie Beauté" (Traité 38 , p. 334), which is the object of contemplation of the Intellect in search of the Transcendent.

What seems to emerge from this conflicting interpretation is the concept of transcendent beauty (cf. "the beauty above beauty" in 32.29), not exactly the transcendent Good itself, but somehow transcending the intelligible beauty. To use Plato's

\footnotetext{
${ }^{40}$ It seems to be the prevalent explanation, supported also by Henry and Schwyzer in: Plotinus (1983), as well as Igal in: Plotino (1985), Hadot in: Plotin (1988), Fronterotta in: Plotin (2007), and Radice in: Plotino (2002). Stern-Gillet (2000, 49 and 53), does not seem to have any doubts, either. Slightly different is the translation of Faggin in: Plotino (2000), who applies "variegated and not variegated" to the Good, but leaves out the pánkalon, and that of Harder in: Plotin (1964), who connects the first two attributes to all-beautiful and the not variegated to the Good.

${ }^{41}$ In his note to translation (Enn. VI ${ }^{2}$, p. 106).
} 
words, "the power of the Good seems to have fled into the nature of the Beautiful", 42 as this beauty is revealed further in the Ch. 33 :

These beautiful things, then, must be measured and limited, but not the really beautiful or rather the super-beautiful; but if this is so, it must not be shaped or be a form. The primarily beautiful, then, and the first is without form, and beauty is that, the nature of the Good.

Not pánkalon, but hypérkalon this time is identified as the nature of the Good. What carries this Beauty (kalloné) ${ }^{43}$ above the intelligible beauty (kállos) is the fact that it is not only shapeless, but also formless (aneideon), thus transcending the realm of intelligible Forms (eide). This makes it more plausible that the "all-beautiful, variegated and not variegated" indeed refer to the beauty of the one-and-many intelligible realm.

\section{Conclusion}

This paper has sought to show, through these instances of Ficino's hermeneutics, that his attempt to bring Plotinus' concept of Love and Beauty closer to what he believed to be Plato's doctrine, and which was in many ways his own, sometimes led him to depart, in some points, from Plotinus and his doctrine of emanation. Nonetheless, his reformulation of the Neoplatonic procession remains solidly grounded in the Enneads, to which he keeps referring even in his commentaries on Plato. This not only confirms that his knowledge of Plotinus went alongside his study of Plato and other authors, but also gives full credit to his role as translator of, and commentator on, Plotinus' corpus.

\section{Bibliography}

\section{Ancient and Renaissance sources:}

FICIN, Marsile (1956): Commentaire sur le banquet de Platon. Marcel, R. (ed.). Paris: Les Belles Lettres.

FICINO, Marsilio (1985): Commentary on Plato's Symposium. On Love. Jayne, S. (transl.). Dallas, Texas: Spring Publications.

FICIN, Marsile (2012): Commentaire sur le Banquet de Platon. De l'amour. Laurens, P. (ed.). Paris: Les Belles Lettres.

\footnotetext{
${ }^{42}$ See Plato's Philebus 64e, which is behind the concept of beauty in these passages, as the text itself seems to suggest (but cf. also "the extraordinary beauty" of the Good in R. 509a).

${ }^{43}$ The expression used here (kalloné instead of the usual kállos) is also found in Plato's Symposion (206d), which is why Hadot translates it as "Beauté transcendente".
} 
FICIN, Marsile (2014): Über die Liebe oder Platons Gastmahl. Blum, P. R. (ed.). Hamburg: Felix Meiner Verlag.

FICIN, Marsile (2017): Commentary on Plotinus. Vol. 4. Enn. III, Part 1. Gersh, S. (ed.). Cambridge - Massachusetts - London: Harvard University Press.

FICIN, Marsile (2018): Commentary on Plotinus. Vol. 5. Enn. III, Part 2 and Ennead IV. Gersh, S. (ed.). Cambridge-Massachusetts-London: Harvard University Press.

FICIN, Marsile (2021): O ljubezni. M. Mihelič (transl.). Ljubljana: Slovenska Matica.

PLOTINI Opera I-III (1964 - 1983): Henry, P. and Schwyzer H. R. (eds.). Oxford University Press. PLOTINS Schriften III (1964): Harder, R. (transl.) Hamburg: Felix Meiner Verlag.

PLOTINUS (1978 - 1988): Enneads I - VI. Armstrong, A. H. (transl.). Cambridge - London: Harvard University Press.

PLOTINO (1985): Enéadas III - IV. Igal, J. (transl.). Madrid: Gredos.

PLOTIN (1988): Traité 38. Hadot, P. (transl.). Paris: Cerf.

PLOTIN (1990): Traité 50. Hadot, P. (transl.). Paris: Cerf.

PLOTIN (1990): Traité sur la liberté et la volonté de l'Un. [Ennéade VI, 8 (39)]. Leroux, L. (transl.). Paris: Vrin.

PLOTINO (2000): Enneadi. Faggin, G. (transl.). Milano: Bompiani.

PLOTINO (2002): Enneadi. Radice, R. (transl.). Milano: Mondadori.

PLOTIN (2007): Traités 38 - 41. Brisson, B. - Pradeau, J.-F. (eds.). Paris: Flammarion.

PLOTINUS (2017): Ennad VI.8. On the Voluntary and on the Free Will of the One. Corrigan, K. and Turner, J. D. (transl.). Las Vegas-Zurich-Athens: Parmenides.

PROCLUS (1963): The Elements of Theology. Dodds, E. R. (transl.). Oxford: Clarendon Press.

\section{Modern sources:}

ARMSTRONG, A. H. (1961): "Platonic Eros and Christian Agape". Downside Review 79, 106 - 120. BUSSANICH, J. (1988): The One and its Relation to Intellect in Plotinus. A commentary on selected texts. Leiden - New York - København - Köln: Brill.

CELENZA, C. S. (2002): "Late Antiquity and Florentin Platonism: The 'Post-Plotinian' Ficino.” In: Allen, M. J. B., Rees, V. and Davies M. (eds.): Marsilio Ficino: His Theology, His Philosophy, His Legacy. Leiden-Boston-Köln: Brill, 71 - 98.

CORRIAS, A. (2020): The Renaissance of Plotinus. New York: Routledge.

GERSH, S. (2019): "Marsilio Ficino as Commentator on Plotinus: Some Case Studies". In: Plotinus' Legacy. The Transformation of Platonism from the Renaissance to the Modern Era. Gersh, S. (ed.). Cambridge University Press: $19-43$.

GOMBRICH, E. H. (1972): "Botticelli's Mythologies : A Study in the NeoPlatonic Symbolism of his Circle". In: Studies in the Art of the Renaissance, vol. 2: Symbolic Images, New York: Phaidon: $31-81$.

HADOT, P. (1957): "Etre, vie, pensée chez Plotin et avant Plotin". In: Entretiens sur l'antiquité classique: "Les Sources de Plotin". Vandoeuvres - Genève: 107 - 157.

HENRY, P. (1948): Les Manuscrits des Enneads. Paris: Editions Universitaires.

KRISTELLER, P. O. (2005): Il pensiero filosofico di Marsilio Ficino. Firenze: Le Lettere (reprint).

LACROSSE, J. (1994): L'amour chez Plotin. Eros hénologique, eros noétique, eros psychique. Bruxelles: Ousia.

NYGREN, A. (1953): Agape and Eros. Philadelphia: The Westminster Press.

PANOFSKY, E. (1972): Studies in Iconology Humanistic Themes in the Art of the Renaissance. (New York: Harper \& Row: Icon editions, (reprint).

PANOFSKY, E. (1970): Renaissance and Renascences in Western Art. London: Paladin. 
PIRENNE-DELFORGE, V. (1988): "Épithètes culturelles et interpretation philosophique. À propos d'Aphrodite Ourania et Pandémos à Athènes". L'Antiquité Classique 57, 142 - 157.

RIST, J. M. (1962): "The Indefinite Dyad and Intelligible Matter in Plotinus". The Classical Quarterly $12(1), 99-107$.

RIST, J. M. (1964). Eros and Psyche. Studies in Plato, Plotinus and Origen. Toronto: University of Toronto Press.

ROBICHAUD, D. J.-J. (2018): Plato's Persona: Marsilio Ficino, Renaissance Humanism, and Platonic Traditions. University of Pennsylvania Press.

STERN-GILLET, S. (2000): "Le Principe Du Beau Chez Plotin: Réflexions sur "Enneas" VI.7.32 et 33". Phronesis 45 (1), $38-63$.

ŠKAMPERLE, I. (2002). “Oživitev mitov in misterijskega izročila v renesansi”. Poligrafi 7 (25 $26,51-78)$

TINKLE, Th. (1996): Medieval Venuses and Cupid. Sexuality, Hermeneutics and English Poetry. California: Stanford University Press.

URŠIČ, M. (2002): “Botticellijeva Primavera kot 'Imago humanitatis'?”. Poligrafi 7 (25 - 26), 181 $-190$.

WOLTERS, A. (1986): "Ficino and Plotinus' Treatise 'On Eros'”. In: Eisenbichler, K. - Zorzi Pugliese, O. (eds.): Ficino and Renaissance Neoplatonism. Toronto: Dovehouse Editions: 189 - 197.

Sonja Weiss

University of Ljubljana

Faculty of Arts

Department of Classics

Aškerčeva 2

SI-1000 Ljubljana

Slovenia

e-mail: Sonja.Weiss@ff.uni-lj.si 